\title{
KONSEP SHALAT, DZIKIR DAN TANDA-TANDA KEMATIAN DALAM NASKAH HAKEKAQ SAMPAJANG
}

\author{
The Concept of Prayer, Dhikr and Signs of Death in The Manuscript of Hakekaq Sampajang) \\ Oleh: Sitti Arafah* \\ * Staf Pada Balai Litbang Agama Makassar \\ Alamat Kantor: Jl. A.P. Pettarani No. 72 Makassar \\ Email: sitti arafah@vahoo.com
}

\begin{abstract}
Abstrak
Penelitian ini menggunakan metode pendekatan tasawuf dan pendekatan filologi sebagai ilmu bantu yang bertujuan mengkaji konsep-konsep tawasufyang termuat dalam naskah Hakekaq Sampajang (HSJ.Hasil kajian dari naskah HS memuat konsep shalat, dzikir dan tanda-tanda kematian yang diungkap melalui konsep tasawuf yaitu adanya penyatuan antara hamba dan manusia yang dikenal sebagai konsep Wihdatul Wujud, di samping penerapan dzikir melalui jalan tarekat.Isi naskah HS terdapat hubungan antara syari 'ah, tarekat, hakikah dan ma 'rifatulah dalam menyingkap tabir Allah SWT melaluipemahaman tasawuf.
\end{abstract}

Kata Kunci: Shalat, Dzikir, Tanda-tanda Zakratul maut.

Abstract

This study usesthe approachof Sufism andphilologyas a scientific approach that aims to help review the concepts contained in the manuscript tawasuf Hakekaq Sampajang (HS). A review of the manuscript HS includes the concept of prayer, remembrance and the signs of death a reexpressed through the concept of mysticism that is the union between the slave and the manknown as the concept of Wihdatul Wujud, in addition to the application of dhikr through the congregation. HS content of the manuscript there is a relationship between Shariah, religious congregations, and ma 'rifatulah hakikah in the veil of Allah SWT through the understanding of Sufism.

Keywords: Prayer, Dhikr, signs of death

\section{PENDAHULUAN}

$\mathrm{N}$ askah sebagai peninggalan tertulis yang di dalamnya terkandung gambaran yang cukup jelas mengenai peristiwa, pengetahuan, falsafah, kepercayaan dan sistem nilai suatu masyarakat pada masa lampau.Pada dokumen tertulis tradisional ini juga dapat ditemukan perihal khusus seperti arsitektur, pertanian, perdagangan, perbintangan, serta hal-hal yang menyangkut kehidupan secara menyeluruh.'

Melimpahnya teks-teks keagamaan terutama dengan unsur tasawuf ini memang tidaklah mengherankan, mengingat kebudayaan yang dimiliki bangsa Indonesia hingga dewasa ini secara keseluruhan merupakan hasil dari proses akulturasi manusia Indonesia dengan peradaban Islam yang oleh Edi
Sedyawaty disebut sebagai salah satu dari tiga pengalaman besar dalam akulturasi Indonesia. Apalagi diketahui bahwa sejak abad XIII bangsa Indonesia telah didatangi oleh para ulama sufi yang dalam proses penyebaran Islam banyak menghasilkan tulisan dan karya yang kini tersimpan dalam bentuk naskah, salah satu di antaranya menyangkut masalah ajaran tasawuf, yang mereka sampaikan kepada masyarakat. ${ }^{2}$

Sejalan dengan pertumbuhannya, maka dalam tasawuf muncullah berbagai aliran yang masing-masing mempraktikkan metode yang ditempuh dalam rangka mendekatkan diri dan menyatu dengan Tuhan-Nya seperti yang dipraktikkan oleh sufi Rabiatul alAdawiyah pada konsep mahabbahnya, Al-hallaj dalam konsep al-Hulul, Al-Ittihad oleh Abu Yazid Al-Bustami, konsep ma'rifah oleh Imam al-Gazali.

\footnotetext{
S.W.R Mulyadi. 1991. Naskah dan Kita. Lembaran Sastra Edisi Khusus; Depok: Fakultas Sastra I, h. 2.

Azyumardi Azra. 1995. Jaringan Ulama Timur Tengah dan Kepulauan Nusantara AbadXII dan XIII. Bandung: Mizan, h. 55.
} 
Dengan demikian, penelitian atas naskah-naskah tersebut tentu saja sangat penting untuk dilakukan. Akan tetapi pada dasarnya yang penting untuk dikembangkan bukanlah semata-mata bentuk penelitian filologinya, melainkan lebih pada apresiasi kita terhadap naskah sebagai bagian dari masa lalu tersebut.

Berdasar dari latar belakang di atas, masalah yang akan dikemukakan dalam penelitian ini adalah:

1. Bagaimana konsep shalat dalam naskahHakekaq Sampajang']

2. Bagaimana konsep dzikir dalam naskah Hakekaq Sampajang?

3. Bagaimana tanda-tanda kematian dalam Hakekaq Sampajang?

Adapun tujuan dari penelitian ini adalah untuk mengungkapkan konsep-konsep tasawuf yang terdapat dalam naskah HS, sementara kegunaan penelitian ini adalah untuk mengaktualisasikan konsep-konsep tasawauf yang terkandung dalam naskah Hakekaq Sampajang.

Sebagaimana umumnya penelitian terhadap naskah-naskah klasik, maka penelitian ini termasuk dalam penelitian kepustakaan (library research) yang objek kajiannya adalah naskah "Hakekaq Sampajang". Dalam mengungkap isi naskah HS, menggunakan metode pendekatan tasawuf untuk melakukan analisis terhadap naskah HS, di samping menggunakan pendekatan filologi sebagai alat bantu untuk menyajikan isi naskah yang akan diteliti. Langkah-langkah yang ditempuh antara lain:

1. Transliterasi, ialah pergantian huruf atau pengalihan huruf demi huruf dari satu abjad ke abjad yang lainnya. Misalnya huruf Arab Melayu ke huruf latin. Transliterasi ialah perubahan teks dari satu ejaan ke ejaan lain sesuai ketentuan.

2. Penerjemahan yang baik adalah dengan menggunakan kalimat yang ringkas dan mampu melukiskan apa yang ingin dikatakan oleh teks yang diterjemahkan ke dalam kalimat indah yang mampu mengekpresikan substansi teks sebagaimana bahasa aslinya.

Tinjauan Pustaka

Dalam penelitian yang dilakukan oleh para ahli tentang fungsi dan peran tasawuf terdapat beberapa model di antaranya: Model Harun Nasution, hasil penelitiannya dalam bidang tasawuf yang terdapat dalam bukunya: Mistisisme dalam Islam, penelitiannya itu mengambil pendekatan tematik yakni menyajikan tema-tema tasawuf yang menjadi jalan untuk mendekatkan dari pada Tuhan dengan beberapa konsep seperti zuhud, al-ma'rifah, mahabbah, albaqa, al-wihdatul wujud dan al-hulul. Pada setiap topik selain dijelaskan tentang isi ajaran dari setiap topik tersebut dengan data-data yang didasarkan pada literatur kepustakaan juga dilengkapi dengan tokoh yang memperkenalkannya. Selain itu Harun Nasution juga mengemukakan latar belakang sejarah timbulnya.

Imam Al-Gazali, juga menjelaskan tasawuf dengan menggunakan metode deskriptif berdasarkan pada Alquran dan Hadits serta pendapat para ulama dan menjelaskan berbagai istilah dalam tasawuf seperti al-hal, al maqam, al haibah, dan lainnya. Dalam kitabnya Ihya Ulum ad-Din. Beliau mengemukakan tentang keajaiban hati, cara melatih dan mendidik jiwa, kitab mencela perbuatan sifat pemarah, iri, dengki, sombong, dan tinggi hati, serta perbuatan tercela lainnya.

Dalam penelusuran mengenai kajian naskah tasawuf telah dilakukan penelitian dan pengkajian pada beberapa naskah yang telah dilakukanoleh Idham terkait konsep pengenalan diri terhadap Allah melalui jalan syariah, tariqah, hakekat dan ma'rifah sehingga manusia mampu mengenai Tuhan-Nya dan beberapa jalan untuk sampai kepadanya melalui tingkatantingkatan dzikir. ${ }^{5}$ Demikian pula telah dikaji oleh La Sakka mengenai Konsep Ma'rifatullah" membahas tentang syariah, tariqah, hakekat, ma'rifah, serta konsep tasawuf mengenai tauhid, ismu jalalah, alma 'rifah dankesempurnaan Allah yakni " Dzatul Buhti", serta tingkatan-tingkatan dzikir yang hendaknya dikerjakan oleh setiap manusia. ${ }^{6}$

Relasi antara Syariah, Tariqat, Hakekat dan Ma'arifah

Sebelum melakukan pengkajian terhadap isi naskah HS terlebih dahulu akan dijelaskan beberapa hal yakni:

Pemaknaan kata Syariah artinya undang-undang atau garis-garis yang telah ditentukan termasuk di

\footnotetext{
Harun Nasution. 1973. Falsafat dan Mistisisme dalam Islam. Jarakta: Bulan Bintang, h. 93.

Imam Al-Gazali. Tth. Ihya Ulum ad-Din, Baerut: Dar al-Fikr.

"Idham. 2008. Issengi Majeppiu, Kajian Terhadap lontarak LKMIX. Makassar: Balitbang Agama Makassar.

'La Sakka. 2009. Kajian Atas Lontarak Ma'rifatullah. Makassar: Balitbang Agama Makassar.
} 
dalamnya hukum halal, haram, makruh, sunnah dan mubah. Segala perbuatan manusia (yang dilakukan oleh seorang muslim) tidaklah keluar dari garis hukum agama. Atas dasar pemikiran ini maka meluaslah arti syariah yaitu meliputi seluruh perbuatan manusia yang dapat dinilai oleh hukum.'

Sedangkan syariah menurut kaum sufi adalah ajaran Islam yang bersifat lahiriah (eksoterik). Karena itu mengerjakan syariah berarti mengerjakan amalanamalan yang lahir (badaniah) dan ajaran atau hukumhukum agama seperti shalat, puasa, zakat, haji, berjihad di jalan Allah, menuntut ilmu pengetahauan dan lain sebagainya.Tegasnya syariah adalah segala peraturan agama yang bersumber dari kitab suci Alquran dan hadits.

Dalam prakteknya kaum sufi dalam melakukan ibadah lebih diarahkan pada pengalaman bhatiniyah oleh karena itu kaum sufi menggunakan istilah fadhilah shalat (keutamaan shalat) atau asras al-shalah (rahasia shalat) untuk mengambarkan makna tersirat dari amalan lahiriah. Kaum sufi dalam melaksanaan syariah kepada Allah berdasar pada penghambaan diri, kepada Allah Swt, dan karena keinginannya berjumpa dengan Tuhan-Nya sehingga mereka menempuh suatu cara yang dinamakan Tareqah (tariqah tasawuf).

Al-Qussyairi mengatakan bahwa setiap syariah tanpa diperkuat dengan hakikah maka tidaklah diterima dan setiap hakikah yang tidak dilaksanakan menurut ketentuan syariah adalah kosong. Dalam hal ini, kata syariah menurut pengertian sebagian orang sufi diartikan sebagai perintah untuk melaksanakan ibadah dan haqiqah diartikan sebagai musyahadah terhadap Tuhan.

Dalam kaitannya dengan tariqah, haqiqah, tidak dapat dipisahkan, bahkan sambung menyambung antara satu dengan yang lainnya. Pelaksanaan ajaran Islam tidak sempurna, jika tidak dikerjakan secara integratif dalam empat hal yaitu: syariah, tariqah, haqiqah dan ma'rifah. Sebagai ilustrasi syariah merupakan peraturan, tariqah merupakan jalan (pelaksanaan) haqiqah merupakan keadaan dan ma'rifah tujuan yakni pengenalan Tuhan dengan sebenar-benarnya. ${ }^{8}$

Dari uraian tersebut di atas, maka dapatlah dipahami bahwa dalam memahami ajaran Islam tidak dapat dipisahkan dari empat hal yakni: syari'ah, tariqah, hakekat dan ma'rifah sebagai pengejawantahan dalam rangka pengenalan Tuhan yang sebenar-benarnya.

\section{PEMBAHASAN}

A. Deskripsi Naskah Hakekaq Sampajang (HS)

Naskah ini ditulis menggunakan bahasa Arab Serang, (tulisan Arab berbahasa Bugis), berukuran, 17x21 Cm, kertas berwarna kecoklatan, pemilik naskah adalah Hj. Tjenang beralamat di Majene Sulawesi Barat. Naskah ini telah digitalisasi oleh peneliti Balai Litbang Agama Makassar dengan kode $\mathbf{H j}$. Tjenang (HT) 01, tebal naskah berjumlah 18 halaman, tinta berwarna hitam, jumlah baris perhalaman 12 baris, memiliki halaman kosong sebanyak 1 halaman, naskah tidak terdapat nama penyalin dan tahun penyalinannya (kolofon). Didalam naskah itu terdapat 4 pasal, 2 pasal yang menjelaskan tentangpelaksanaan shalat yang tidak terbatas pada konsep syariat semata melainkan pelaksanaan shalat dalam konsep hakikat, tareqat menuju hakekat shalat yang sebenarnya sehingga konsep yang ada dalam naskah HS lebih cenderung pada pemahaman tasawuf yakni akan kesatuan Allah dan mahkluknya yang dikenal dengan konsep Wahdatul Wujud.

Naskah HS membahas 4 pasal, 2 pasal. Pasal pertama dan kedua membahas tentang shalat, rukun, suju' ruku, i'tidal, duduk di antara dua sujud,qassad, ta 'rud dan to 'yun, pasal tiga membahas mengenai ketika ajal telah dekat (sakraturl maut) maka diperintahkanlah senantiasa mengingat Allah dalam bentuk dzikir yang terdiri dari empat macam tingkatan dzikir sehingga kelak kita akan memperoleh Nur Muhammad (Haqiqat Muhammad) dan pasal keempat membahas tentang tanda-tanda kematian bagi seorang hamba.

\section{B. Konsep shalat}

Shalat adalah ibadah tertinggi. Shalat sering disamakan dengan "Sembahyang". Sembahyang adalah ibadah atau pemujaan yang dapat dilakukan dengan bentuk, bahasa, dan kondisi apapun. Permohonan doa seorang anak untuk sebuah mainan adalah sama halnya dengan meditasi wali sufi. Di lain pihak shalat dapat pula dilakukan hanya pada waktu tertentu, dengan cara yang sudah ditetapkan, dengan syarat-syarat tertentu. '.

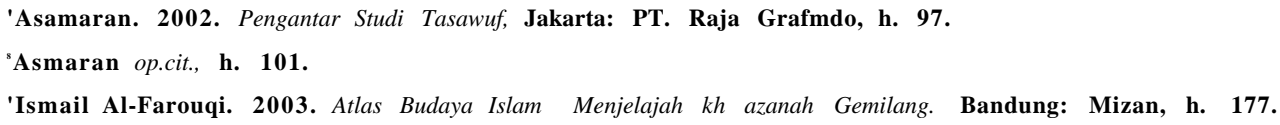


Tujuan terpenting dari tasawuf adalah untuk $m a$ 'rifatullah penyingkapan langsung, dan pengkajian garis hubungan antara Tuhan dengan mahluk terutama hubungan kedekatan manusia dengan Tuhan, dekat dalam arti melihat dan merasakan kehadiran Tuhan dalam hati, dekat dalam arti berjumpa dengan Tuhan dan penyatuan manusia dengan Tuhan sehingga terjadi monolog antara manusia yang telah menyatu dengan iradat. ${ }^{10}$

Diwaktu menunaikan shalat hendaknya engkau selalu mengingat: Apakah engkau suka jika termasuk kaum yang menunaikan shalat, tetapi pada hakekatnya mereka tidak shalat. Atau apakah engkau suka jika hatimu khusyu' dan ruh merasa sangat senang bermunajat kepada Rabb Jalla wa 'Ala. Kesemua ini sumbernya adalah ma 'rifatullah (mengenal Allah) keagungan, keperkasaan dan kesempurnaannya."

Memahami hakekat dari sesuatu termasuk shalat untuk menyingkap tabir atau menyatu dengan Tuhan maka harus ditempuh dengan jalan tariqah menuju hakekat dan $m a$ 'rifah yang sesuai dengan koridor yang telah digariskan oleh syariahKetika seseorang hendak melaksanakan shalat maka perbuatan itu diawali dengan cara berdiri mengawali shalat. Apabila telah berdiri dengan tegak dan menghadap kiblat, ketika itu tubuh dalam keadaan tenang, disaat itu hati sudah dalam kondisi khusyu' sehingga tidak dikatakan shalat dalam keadaan lalai dan seluruh shalatnya disebut sebagai orang yang mendirikan shalat untuk mengingat Tuhan.

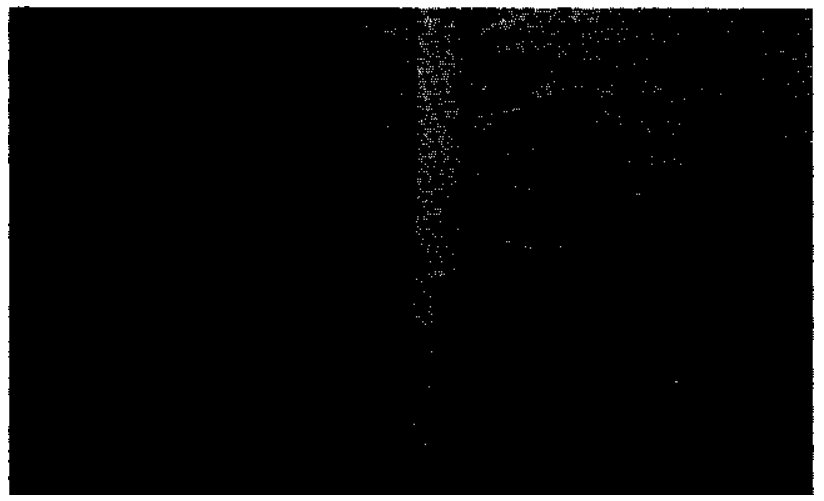

Kutipan teks isi naskah pada pasal pertama

"Pashlun pannesaiengngi iyyanae haqeqaq tongengtongenna sampajang. Bicara hakekaqna mulamulanna rukun maeloki tettong massempajang. Tettopi alepue, apa alepumitu tettong massempajang.
Battuanna menreqpi naffaseqmu nainappa tettong, bettuannna tettopi nyawamu, natettong tubummu, apa' tammakulleitu tubue patettong nyawa, nyawamitu patettong tubue, aja nalaing gau 'na nyawa samammunaritu to mappaddua mitu, namunawanawa lao mappasewwa ri Puang-E... .dst.

Narekko maelono ruku, nok pi nappasaqmu murukuq, tidalako menreqpi nappaseqmu muwakkada "samiallahu" sujudko nok pi nappasaqmu musujudto, lawang sujud nok pi nappaseqmu musjudto lawang sujudko menreqpi nappasemu muwakkai ulummu menre. Iya taola menre iya muturusi nok, apa iyanatu imanna nabitta saw, iyatona imanna uwallie, iyatona riaseng imang tarri imangi, iayanaritu riaseng mamma-mata "IsmuJalalah", rilalengatinnarinoqna nappaseqmu, narekko makkuwanitu riasengitu layakna sampajang nawawa massampajang... narekko tammakkuwai tammanassaitu massabajang mating. Narekko mubangngi takabereqmu palaloni nok nappasa'mu mupasirapekengngi. Makkadasi nabitta saw ala massai-sia muwa passambajanga sangadinna tekkoqmi. Narekko engka tau pakei makkuwaeto rilaleng sampajang iyanaritu tau assa ri imang, iyanaritu riaseng tammamuqmang... dst

Dalam naskah HS dijelaskan bahwa shalat itu diibaratkan dengan huruf Alif yang berdiri tegak dan tunggal, karena Alif itulah puncak dari segala yang menggerakkan tubuh dan nyawa, karena sesungguhnya tanpa Alif maka tubuhmu tidak akan mampu menggerakkan nyawamu. Demikian pula ketika hendak berdiri maka napas harus betul-betul telah naik barulah kita berdiri sehingga pikiran itu harus betul-betul tertuju pada Allah semata, karena sesungguhnya gerak tubuh dan nyawa adalah perbuatan Tuhan, jika telah demikian adanya maka layaklah kita untuk berdiri menuanaikan shalat jika tidak demikian maka sama halnya menduakan Tuhan, dengan kata lain gerakan tubuh dan nyawa harus sehias sekata sehingga jelaslah pula imam yang ada pada tubuh kita., dimana gerakan imam dan makmun bukan gerak karena keinginannya akan tetapi gerakan imam adalah karena gerakannya nyawa. Oleh karena itu, imam shalat tidak lain adalah Alquran (kata-kata Tuhan) sehingga tidak akan berpisah antara perkataan dan orang yang mengatakannya (Tuhan). Jika telah demikian pemahaman kita tentang hakekat shalat dan imam, maka sesungguhnya shalat itu disebut dengan shalat dzahiriah yakni segala perbuatan dalam shalat

\footnotetext{
10 Prof.H.A.Rivay Siregar. 1999. Tasawuf dari Sufisme Klasik ke Neo-Sufisme. Jakarta: Raja Grafindo Persada, h. 57.

"Abu Thalhah Muhammad Yunus Abdusattar. 2005. Manakah Orang Yang Khusyu'Dalam Shalat. Jakarta: Darul Falah, h. 217.
} 
karena kehendak dan gerak Tuhan. Namum demikian sebaliknya jika seseorang dalam melaksanakan shalat tanpa memahami hakekatnya disaat akan memulai untuk berdiri dan membuang takbirnya maka shalat yang ia lakukan itu akan jatuh pada tempat yang kosong dengan kata lain akan menjadi sia-sia tanpa memperoleh apa-apa dari shalatnya kecuali hanya lelah.

Dalam naskah "Lalengnna To Salamae" dijelaskan pula pemahaman tentang shalat yakni ketika hendak melakukan shalat maka yang terlebih dahulu harus dipahami cara menghadap dalam shalatmu. Dalam naskah tersebut dijelaskan "Alepu tettong, ha ruku, mim suju dan daleng tudang. Sedangkan sa'na Allah Ta'ala tettong, sifa'na roko, asenna sujud dan winru 'na tudang " Artinya: Alif yang berdiri, "Ha" yang ruku', "Mim" yang sujud dan "Dal" yang duduk, selanjutnya dzat Allah itulah menandakan berdiri, sifat Allah itu menandakan ruku, nama Allah menandakan sujud dan bentuk Allah menandakan duduk.

Dalam memahami hakekat shalat maka yang harus dipahami pula adalah ketika akan melakukan sujud. Dalam naskah HS penulis menjelaskan tentang $r u k u^{\prime}$ dilakukan sesuai dengan keteraturan napas ketika ruku' hendaknya napas telah benar-benar dalam keadaan turun barulah kita ruku', adapun / 'tidal jika telah yakin bahwa napas telah naik barulah membaca doa' / tidal, demikian pula sujud ketika napas telah turun dan duduk diantara dua sujud ketika napas telah naik barulah mengangkat kepala. Karena kesemua itu adalah imam yang tidak diimami, jika telah demikian adanya maka akan menuju pada "Ismu Jalalah". Demikian pula ketika akan memulai membuang atau mengangkat takbir maka hendaklah napas itu dalam keadaan turun setelah itu barulah kita menyatukan takbir kita karena yang demikian itu layak pada Nurung Muhammad.

Pada praktik beberapa tarekat khususnya tarekat Qadariyah kelompok tarekat ini menganjurkan apa yang disebut $p d s-i$ anfds, yakni mengatur nafas sedemikian rupa sehingga dalam proses menarik dan menghembuskan napas asmd 'Allah bersirkulasi dalam tubuh secara otomatis. Kemudian diikuti dengan muraqabah atau komtemplasi. Dianjurkan untuk berkonsentrasi pada sejumlah ayat Alquran ataupun sifat-sifat ilahiyah tertentu hingga sungguh-sungguh terserap ke dalam kontemplasi."
Dalam Tarekat Syattariyah di Sumatera Barat terdapat satu doktrinyang salah satu substansi ajarannya yakni pengajian tubuh. Materi pengajian tubuh itu sendiri bermuara pada satu keyakinan bahwa tubuh manusia memiliki dua sisi: bagian yang kasar (lahir) dan bagian yang halus (batin). Pada hakekatnya, bagian tubuh lahir tidak mempunyai kehendak apa-apa, karena bagian tubuh batinlah yang menggerakkannya. Tubuh lahir sendiri dalam konsep tasawuf merupakan bagian dari apa yang disebut a ydn khdrijiyyah, terdiri dari empat unsur yaitu api, angin, air, dan tanah.

Dengan demikian bahwa dalam memahami hakekat pelaksanaan shalat sebagai ibadah yang dilakukan oleh tubuh, maka terlebih dahulu memahami hakekat tubuh itu sendiri bahwa sesungguhnya gerakan yang terjadi pada tubuh manusia bukanlah karena gerakan tubuh kasar melainkan gerak batin dan yang menggerakan adalah yang menciptakan gerak itu sendiri, sehingga dalam melaksanakan shalat hendaklah pikiran dan hati hanya tertuju pada Allah Swt semata.

\section{Konsep dzikir}

Pasal ketiga, dari naskah yang dikaji menjelaskan tentang ketidakmampuan seseorang disaat ajal akan segera tiba, maka bersegeralah untuk bertaubat dan memohon ampun kepada Allah SWT, atas semua kesalahan dan dosa yang telah diperbuat selama mengarungi hidup di dunia. Setelah melakukan taubat maka ada jalan yang harus ditempuh dalam rangka menghadapi zakratul maut yang oleh penulis naskah menjelaskan bahwa hal yang harus ditempuh dengan melakukan dzikir.

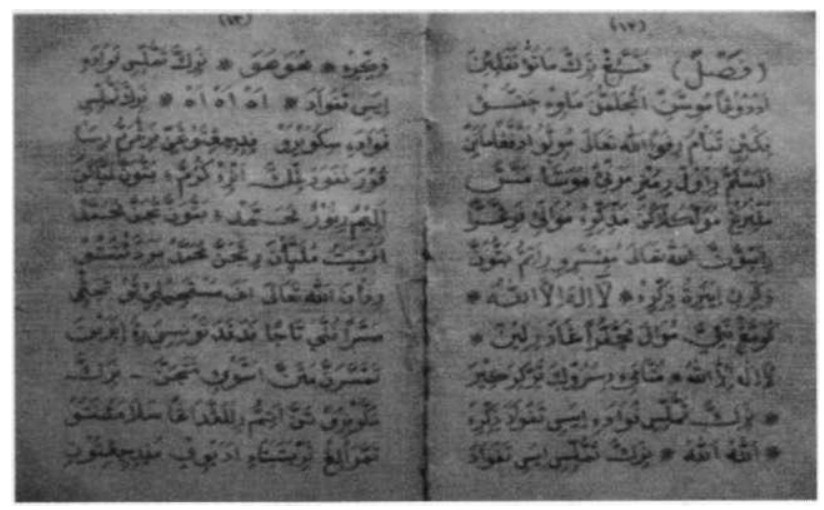

Kutipan Isi naskah HS

Fashlun pannesaingngi narekko matu napoleini adodongeng, muwissengni ajjalemти тсrwe cappu' pukaini toba'mu ri Puang Allah ta'ala, muwellau 
addampengmanengni appasalammu, riolo, rimunri, marenni, mawessa, mallinrung, muwallaku-lakuni massikkiri, muwalai paringerang riassewwanna Allah ta 'ala mupaasseriwi ri atimmu. Battuanna dzikkiri'e iyanaritu dzikkiri "La ilaha Illallah" kuwammengi naiya muwala paccappureng adang ri lino "La Ilaha illalah " Muttamai ri syuruga tarrikirakira, narekko temmulesi puadai iyasi tapuada dzikkiri "Allah-Allah", narekko temmulesi puadai iyasi tapuadadzikkiri "Huwa-Huwa", narekko temmulesi puadai, iyasi tapuada "Ah, Ah, Ah, $A h$ " narekko temmulesi puada sikuwaero padecengitongengni paringerangmu risa 'pura napuadagekko angre gurummu. Battuanna laya 'ni alemu ri nurung Muhammad, battuanna tajanna Muhammad, apasiatu mulaya 'na ri tajanna Muhammad maraddenatu ri dzaqna Allah ta 'ala apa mustaheleitu tajang'e massarangpunna 'e tajang, pada-pada tonisiya ritu ibaraqna tammassaranna matanna esso 'e mat aj anna... dst..

Penjelasan dari naskah HS didalamnya terdapat empat tingkatan zikir yang harus dilafalkan oleh seseorang ketika menghadapi zakratul maut adapun ke- 4 (empat) tingkatan dzikir yakni:" Id ilaha ilia Allah" , keduadzikir "Allah Allah", ketiga dzikir " Huwa-Huwa" dan keempat dzikir "Ah $A h^{\prime \prime}$.Jika keempat dzikir ini tidak mampu lagi diucapakan maka perbaikilah ingatan terhadap layaknya dirimu pada Nurung Muhammad atau Nur Muhammad yakni tetap pada dzat Allah, karena sesungguhnya mustahil berpisah antara cahaya dengan yang memiliki cahaya, jika telah demikian hatimu niscaya engkau akan selamat dengan tanpa keraguan di dalamnya. Selanjutnya seorang hamba dalam menghadapi zakratul maut hendaknya dalam keadaaan husnu dzanni yakni senantiasa beranggapan baik terhadap Allah bahwa Allah akan memberiku keselamatan dan menjauhkanku dari segala siksaan, senantiasa dirahmati oleh Allah dan terhindar dari kematian dalam keadaan kafir.

Dzikir adalah salah satu jalan (tarekat) yang ditempuh oleh seseorang hamba dalam menghadapi dzakratul maut sehingga hatinya senantiasa mengingat kepada Allah Swt, dalam melakukan zikir di saat ajal menjemput adalah dengan mengucapkan zikir "la ilaha ilia Allah" yang oleh para ahli tarekat mengatakan zikirnya tubuh, ketika itu tak mampu lagi dilakukan maka ucapkan zikir "Allah Allah" atau zikirnya hatinya, jika itu tak mampu lagi diucapkan maka berzikir dengan mengucapkan "huwa huwa ", atau zikirnya nyawa, jika itu tidak mampu lagi diucapkan maka ucapkan "Ah $A h$ ", atau zikirnya rahasia. Keempat macam ucapan zikir ini hendaknya dipahami oleh seseorang sehingga akan jelaslah ke mana arah akan dituju setelah ajal menjemput.

Dalam beberapa naskah dijelaskan mengenai tingkatan-tingkatan zikir yakni zikir " Id ilaha ilia Allah" merupakan zikirnya tubuh adalah hakekatnya segala sesuatu yang disebut pula "Alam Insan", zikir "Allah Allah" merupakan zikirnya hati dan hakekatnya tubuh disebut pula" Alam Ajsam", zikir Huwa Huwa, merupakan bentuk manusia, hakekatnya hati dan zikirnya hati disebut pula "Alam Misal", dan zikir "Ah $A h A h$ " dinamakan martabat tujuh, tiga yang tetap dan empat yang baru, dan tidak seorangpun yang mampu mengetahuinya kecuali Tuhanlah yang menjelaskannya sendiri, yang disebut pula " Alam Arwah".

Dalam Tarekat Khalawatiyah zikir diajarkan tiga macam ditambah satu zikir khusus:

1. Zikir" la ilaha ilia Allah", yang disebut zikir ndifitsbat:" la ilaha sebagai yang dinafikan atau yang ditiadakan dan ilia Allah" sebagai itsbatnya atau penegasan yang merupakan satu-satunya yang abadi.

2. Zikir "Allah Allah", yang disebut zikir ismu jaldlah.

3. Zikir "Huwa Huwa ", yang disebut zikir ismu alisydrah.

4. Zikir "Ah $A h$ ", merupakan zikir tertinggi karena sudah ma 'rifatullah( mengenai Allah).

Dalam Kitab Zubdat al Asrar, Al Makassari menerangkan tentang tingkatan-tingkatan dalam zikir. Zikir " Id ilaha ilia Allah "adalah zikir orang awam, zikir "Allah Allah" adalah untuk orang khawas dan Zikir "Huwa Huwa" untuk orang khawas al-khawas.

Semua itu untuk membuka jalan mencapai tahap tertinggi yang dinamakan al- 'ubudiyah al-muthlaqa, (pemujaan tak terbatas). Orang yang mencapai tahap ini berarti telah mencpai pusat wujudnya dan karenanya dinamakan manusia universal (al-insdn al-kdmil). Dengan mencapai manusia al-insdn al-kdmil seorang hampa melepaskan dirinya dari wujud alegomrisnya (al-wujud al-majdzi) masuk ke dalam "kehampaan" nya, yaitu non eksistensi ('udum al-haqiqi). Kehampaan dianggap Tuhan sebagai cermin (mir 'ah) 
dari dirinya. Tuhan lebih jauh raengungkapkan diriNya (Tajalli) kepada hamba-Nya itu. Dengan kata lain hamba yang telah demikian terserap (fana) ke dalam eksistensi Tuhan akan mampu mengenali rahasia-rahasia Tuhannya. Dia selanjutnya melalui penglihatan-Nya, mendengar dengan pendengaranNya menggapai dengan tangan-Nya, berjalan dengan kaki-Nya, berbicara dengan firman-Nya, berpikir dengan pikiran-Nya.Namun bagaimana kesatuan hamba dengan Tuhan, meski hamba mampu memasuki eksistensi Tuhan manusia tetap manusia dan Tuhan tetap Tuhan.'

Dalam Kitab Kifdyat al-muhtdjin, dikemukakan proses penciptaan manusia itu dengan tahapan zikir tauhid "Id ildha ilia Allah", kata Id dihubungankan dengan alam insan, kata ildha dengan alam ajsam, kata ilia, dengan alam arwah, dan Allah dengan alam malakut. Sedangkan alam qudus adalah tingkatan tertinggi yang dihubungkan dengan zikir Hit, dalam dunia tarekat dianggap sebagai ungkapan zikir yang paling dalam. ${ }^{15}$

Tentang dzikir sendiri, pengarang menyebutkan ada empat tingkatan pertama: zikir jalt, yang merupakan tingkatan terendah, dengan tujuan untuk mensucikan tubuh lahir, kalimat zikirnya adalah " Id ildha ilia Allah" tingkatan kedua adalah zikir khafl, dengan tujuan untuk mensucikan hati kalimat zikirnya adalah "AlldhAlldhAlldh", ketiga zikir sirri, dengan tujuan untuk mensucikan nyawa zikirnya "Hu Allah", dan zikir tertinggi atau yang keempat adalah zikir maishuri, dengan tujuan untuk mensucikan ruhani kalimat zikirnya "Allah $\mathrm{Hu}$ "."

Mencermati penjelasan di atas bahwa zikir adalah suatu paktek spiritual yang senantiasa melatih seseorang untuk melantunkan asmd Allah, baik pada waktu dalam keadaaan sehat terlebih ketika ajal tiba. Dengan memahami konsep zikir dalam ajaran tasawuf, maka akan membawa seseorang pada penyatuan dengan Tuhan-Nya dengan mengetahui hakekat dirinya maka akan mengetahui hakekat Tuhan-Nya.

\section{Tanda-tanda Kematian}

Pasal empat adalah pasal yang menjelaskan bahwa barang siapa di akhir hidupnya melihat tandatanda kematian pada dirinya dan yakin bahwa tiada
Tuhan selain Allah dan Muhammad adalah Rasul-Nya, dan memahami hakekat dirinya niscaya memahami pula hakekat Tuhannya dan Muhammad adalah hakekat dari Nurung Muhammad.

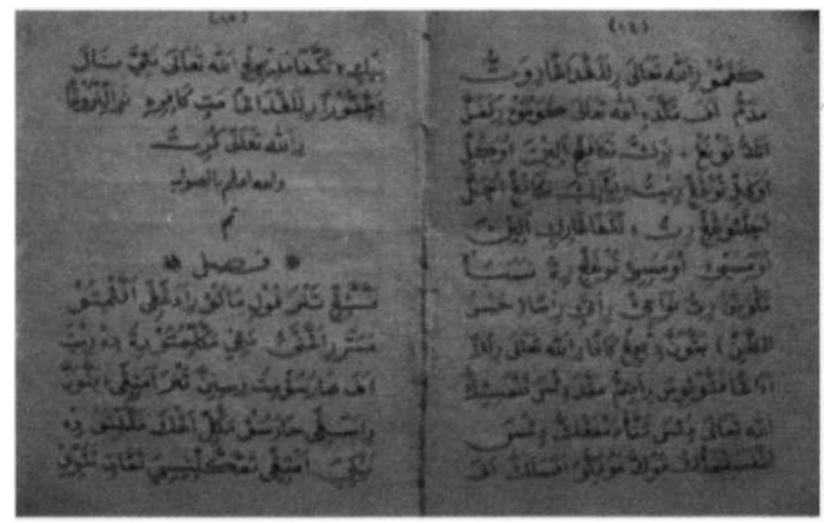

Kutipan isi pasal keempat

Fashlun pannesaingengi tanra polematu riadagengnge, ерра' mitu maserro riangattai na makkulingmuritu, dekmitu apa harusumitu risininna tanra amatengnge. Battuanna riasenge harusu mitu makkulle angka makkulle tu dek naikiya amatengnge tammakullenisiya teammate tauwe. Rekko nadapini ajja/etta naiya to risaliwenna eppae maegatu tanra nae paccoba manengmuwatu, naiyakiya eppae ripuadae tanra amatenna sie tanra pammasetoni. Rekko engkani taita waji 'na tauwe mappasang ripaddimunritta, narekkoengkani ri ita. Seuwwani: mitai matu tajang maserropisita tajanna, natajanna essoe. madduanna, mitai matu tajang maserro mattaro lettu manangngi ri langi pitu susung'e, nadekna alawang pakkita ri arasy, mattelunna mitai matu tajang maserro tannakuwa angkamuwa sewwa oroane mappake makudara pole tettong riataunna Nakkatenreiwi pajjelo ' ataunna nakkeda ri idi' eh siajikku bokorini lino banua mapettangnge mulao ri ahera banua matajangnge, naiya banua Allah ta 'ala muwa missengngi, nabitta naritu Muhammad Saw poleni riiko riwettu madammu, salamanotu tammarauleng aja mubata-batai, baliiwi akkadako "Ashadu Allahilaha illalah wa annaka muhammadun rasulullah" battuanna uwissengngi majeppu dek Puang sangadinna Allah ta'ala, uwissengngi toi majeppu Muhammad surona Allah ta'ala. Maeppa'na mitai matu tajang tenrisseng maseng tajanna.Natakko engkamuwa, takko dekmuwa, battuanna purai engkai purai deksi pura dek, engkasi, nasuju manengtu muita sininna ripancajie

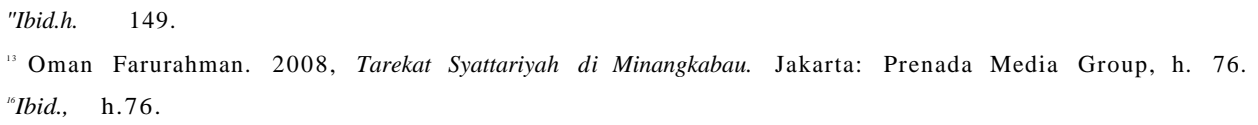


iyamanang, cappu'natu, tanrewetona ri linoe. Naiya nyamenna pappeneddimmu ri Allah ta 'ala muwa missengngi, iyarega nyamenna assiduppanna orowane, makkunrai riwettu messu 'na manni 'na. Narekko makkuniro, ikonatu riaseng tomate massaniyasa naroloe' pammase lao ri kubburue muwarang, riputtama ri syuruga tanricalla, mabelanisa ala risessa ri Allah (a'ala muwa missengn gi patujii. Wallahu a 'lam bi shawab.

Pasal empat, dari naskah HS menjelaskan tentang keharusan mengetahui tanda-tanda kematian (zakratul maut) karena setiap manusia akan mengalami kematian yang tidak dapat dielakkan oleh setiap manusia. Tanda kematian yang dijelaskan dalam naskah ini ada empat macam jika telah terlihat tanda itu pada diri seseorang maka wajiblah ia berpesan kepada orang yang akan ditinggalkannya, adapun tanda-tanda yang dimaksudkan. Pertama, terlihatnya cahaya yang melebihi cahaya matahari, kedua, terlihatnya cahaya yang sangat terang dan terus naik ke langit ke tujuh dan tidak ada yang mampu menghalanginya untuk melihat Arsy, ketiga, terlihatnya cahaya yang tidak ada bandingannya dan akan tampak seorang'laki-laki yang memakai pakaian yang berwarna hijau dan berdiri disisi kanan lalu mengucapkan perkataan "hai saudaraku tinggalkan dunia yang penuh dengan permainan dan kegelapan dan menuju pada kampung/ tempat yang penuh dengan cahaya yakni akherat yang merupakan kampung Allah Swt, dan sesungguhnya yang datang kepadamu adalah Muhammad Saw, maka janganlah engkau ragu maka jawablah dengan mengatakan 'Asyhadu Alldhildha illdllah wa annaka muhammadun rasulullah". Keempat, kelak akan terlihat cahaya yang tidak mampu diketahui bagaiamana cahayanya, kadang nyata dan kadang tidak nyata dan semua yang diciptakannya akan bersujud, maka berakhirlah kehidupan dunia. Orang-orang yang mendapatkan tanda-tanda kematian yang demikian itu adalah yang mereka yang senantiasa mendapatkan rahmat dari Allah Swt, dan kenikmatan yang dirasakan hanya Allah yang mengetahuinya atau layaknya ketika suami istri bertemu dan keluar maninya, jika telah demikian maka engkau mati yang senantiasa mendapat rahmat dan akan terhindar dari siksa kubur dan masuk ke dalam surga tanpa disiksa.

\section{Analisis Isi Naskah HS dan Relevansinya}

Setelah menguraikan pasal demi pasal dari naskah HS maka dapat dipahami bahwa konteks-konteks dan tema isi naskah adalah antara syariat sebagai kunci, sebuah praktik ibadah tidaklah sama sekali bertentangan dengan ajaran tasawuf bahkandi antara keduanya saling melengkapi bahkan dalam memahami hakekat suatu ibadah harus terdapat empat rangkaian yakni syari't, tareqat, hakekat dan ma'rifah (penjumpaan dengan Tuhan).

Dalam Kitab Zubdat al-Asrdr, kitab ini menerangkan tentang pelaksanaan ajaran tasawuf yang benar adalah yang mengikuti syari'ahNabi secara lahir batin. Al Makassari menegaskan orang yang hanya bersandar kepada syari'ah masih lebih baik daripada orang yang mengamalkan tasawuf namun mengabaikan syari'ah, orang yang demikian sebagai zindiq (pemikir bebas) dan mulhid (sesat) yaitu orang yang percaya mereka akan dapat semakin dekat dengan Tuhan tanpa melakukan ibadah seperti shalat dan puasa. ${ }^{17}$

Al-Kuruni dalam mukaddimah kitab Ithdf alDhaki, tidak kurang dari enam di antara tujuh hal yang dikemukakannya adalah berkaitan dengan penjelasan bahwa ritual tasawuf tidak boleh bertentangan dengan prinsip-prinsip syari'at yang mengatur ritual ibadah manusia dengan Tuhan-Nya. Al-Kuruni menegaskan bahwa kendati seseorang mampu meningkatkan derajat spritualnya pada tingkat kashf (terbukanya tabir hakekat), hal itu tidaklah berarti ia gugur dalam kewajiban syati'atnya seperti: shalat, zakat, puasa, haji dan sebagainya, karena kewajiban beribadah dengan melaksanakan syari'at yang dicontohkan oleh Nabi Muhammad Saw itu, berlaku hingga seseorang meninggal, meskipun kadar dan tekniknya disesuaikan dengan situasi dan kondisi yang bersangkutan. ${ }^{18}$

Terkait pelaksanaan doktrin-doktrin tasawuf yang terjadi di Tanah Melayu, Al-Kuruni menegaskan bahwa inti terjadinya penyimpangan tersebut adalah karena adanya ketidakseimbangan antara pengalaman tasawuf sebagai ilmu batin (eksoteris) dengan ilmu syari'at sebagai ilmu lahir (eksoteris). Dalam hal ini, para pelaku tasawuf dianggap oleh Al-Kuruni sebagai min gairi itqdnin li 'ilmi shartat al-mustaf al-mukhtar salld Alldhu 'Alaihi wa sallama; mengesampingkan aspek syari'at yang diajarkan Nabi Saw.

Demikian pula hal yang sama diungkapkan oleh Abdurauf dalam kitabnya Tanbih al-Mdshi dan Kifayat al-Muhtdjin ini persis seperti apa yang menjadi kecenderungan Al-Kuruni dalam Ithdf al-

Sri Muliaty, Op.Cit.X 149.

Oman Faturahman, Op. Cit, h. 104-105. 
Dhaki. Al-Kuruni menegaskan bahwa perilaku tauhid al-wujud (menegaskaiww/wof) yang sering menjadi tema sentral tidak harus dipahami sebagai menafikan sifat trasendensi Tuhan, apalagi secara mutlak (Ithdf al-Dhaki). ${ }^{19}$

Doktrin itu juga tidak harus dipahami sebagai bertentangan dengan ilmu syari'at yang berbasiskan Alquran dan hadits Nabi, serta selalu mengedepankan amr ma 'rtif nahy munkar. Oleh karena itu, pernyataan wujud oleh seorang hamba dengan wujiid Tuhan-Nya (wahdat al-wujud) bisa saja terjadi tanpa menafikan kewajiban beribadah dengan melaksanakan syariat yang dicontohkan Nabi Saw. Bagi Al-kuruni doktrin dan praktik ilmu hakekat dibangun dibawah landasan ketentuan-ketentuan syari'at. Oleh sebab itu, setiap pelaku mistis boleh saja berharap mendapatkan kepercayaan menjadi "kekasih" Tuhan, tetapi pada saat yang sama juga harus tetap mempraktekkan doktrin syaria'at yang diajarkan oleh Nabi Saw.

Konteks tasawufdalam naskah HS dapat dipahami adanya konsep Wahdatul Wujud, yang membawa kepada pemahaman bahwa makhluk (manusia) dan Al-Haqq (Tuhan) sebenarnya adalah satu kesatuan dari wujud Tuhan, sedangkan wujud manusia menjadi bayang dari wujud Tuhan. Sebagai ilustrasi tentang paham ini adalah bagaikan seorang manusia yang melihat dirinya dalam cermin yang diletakkan di sekelilingnya. Di dalam cermin itu, ia melihat dirinya lebih banyak, tetapi sebenarnya dirinya hanya satu. Harun Nasution mengutip pendapat alQhasani dalam Fuslhulul Hikam menjelaskan paham ini, bahwa wajah sebenarnya satu, tetapi jika engkau perbanyak cermin itu menjadi banyak. ${ }^{20}$

Manusia adalah hamba Tuhan karena Tuhan beriluminasi secara dzati-Nya pada manusia (tajalli dzatinya) sehingga manusia adalah dzat Tuhan, karena kejadiannya yang demikian itu disebut insan kamil atau nuskhat Ilahi. Sedangkan makluk selain manusia hanya menerima pancaran tajalli (asma) saja, sehingga hanya beberapa aspek saja yang sama dengan Tuhan. ${ }^{21}$

Menurut Abdurauf, alam hanya merupakan bayangan Tuhan, tidak bisa menjadi wujudnya alam.
Alam tidak identik dengan Tuhan secara mutlak dengan Tuhan, dan oleh karena itulah, Tuhan bersifat transenden. Alam termasuk manusia di dalammya, dengan demikian tidak memiliki wujud sendiri karena itu hanya merupakan bayangan Tuhan, atau bahkan hanya bayangan dari bayangan-Nya, kehadiran bayangan itu tergantung pada ada dan tidak adanya sumber bayangan itu. Oleh kerena itu, wujud hakiki yang sebenaranya adalah sumber bayangan tersebut segala sifat yang melakat padanya. ${ }^{22}$

Demikian Abdurauf mengakui bahwa seorang hamba dapat naik martabatnya mendekati Tuhan (taraqqi), namun pada hakekatnya dia tetap sebagai manusia, mahkluk-Nya, kegaiban ke alam penampakan melalui berbagai tingkatan perwujudan (tanazzul) meskipun Sang Pencipta. Artinya hakekat manusia tidak akan berubah menjadi hakikat Tuhan demikian pula sebaliknya, walaupun pada zaman azali sekalipun. ${ }^{23}$

Ibnu Arabi menggunakan sejumlah simbol-simbol dalam menjelaskan hubungan ontologis antara Tuhan dengan alam. Salah satu simbol yang digunakan adalah antara makanan dan yang dimakan. Dari satu segi alam adalah makanan bagi Tuhan, sedangkan disisi lain Tuhan adalah makanan bagi alam. Jadi secara timbal balik masing-masing adalah makanan dan yang dimakan bagi yang lain pada waktu yang sama. Hal tersebut menunjukkan bahwa yang disinari dan yang menyinari saling menyatu, Tuhan bertajalli terhadap alam, karena adanya alam disebabkan Dzatnya Tuhan yang bertajalli. ${ }^{24}$

Demikian pula perbuatan Tuhan yang dzahiriah. Setiap manusia mempunyai dua aspek yaitu aspek yang nampak (al-zahir) dan aspek yang tidak nampak (albatin).Aspek yang nampak biasa disebut dengan bentuk fisik badaniah sedangkan yang tidak nampak disebut Ruh. Keduanya saling berpengaruh pada manusia, yakni ruh yang menggerakkan dan mengatur segala gerakan yang dilakukan oleh fisik badaniah, sehingga jika tidak ada ruh yang menggerakkan dan mengatur, maka ia tidak akan dapat disebut sebagai manusia, tetapi hanya berbentuk manusia yang tidak

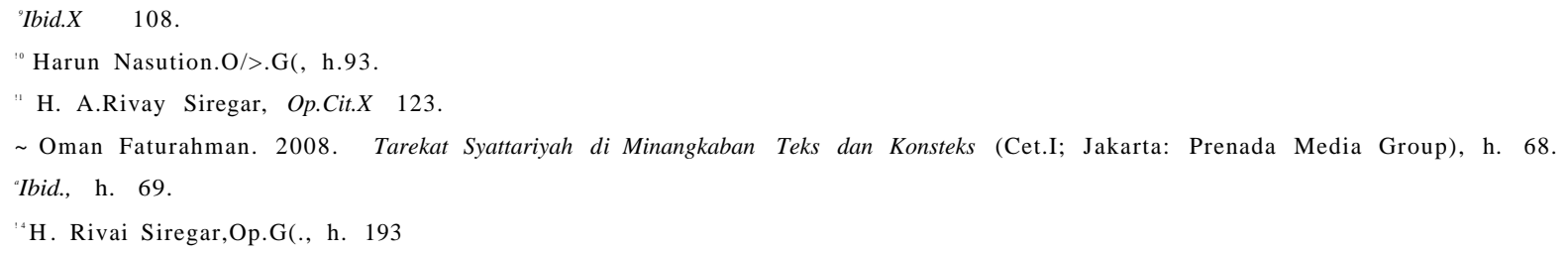


berbeda dengan sepotong kayu atau batu. Dengan demikian ruh-ny a alam yang ada dalam bentuknya tidak lain adalah al-haqq.

Dengan demikian, yang tampak memuji yang tampak dengan dia dengan zahir-Nya memuji batinNya, sebagaimana manusia. IbnuArabi berpandangan bahwa tidak ada garis pemisah antara yang memuji dan dipuji, sehingga yang tampak dan tidak tampak adalah dua nama dan sifat dari satu wujud, yaitu penyatuan antara yang zahir (al-khalq) dan yang batin (al-haqq) dan inilah yang disebut dengan "Wahdat al-wujud"

Tingkatan kemampuan setiap sesuatu untuk menerima tajalli al-haqq ditentukan oleh kesiapan. ${ }^{25}$ Yang dimilikinya. Al-haqq adalah yang Esa dan melakukan tajalli dengan keesaannya, tetapi kesiapan masing-masing dari segala sesuatu dalam alam untuk menerima tajalli berbeda satu sama lain. Setiap sesuatu mempunyai karakter tersendiri, sifat-sifat yang unik, karena itu memiliki kapasitas pula dalam menerima tajalli.

Manusia dipandang sebagai mahluk yang mempunyai kemampuan jasmani, rohani dan kecerdasan untuk mendekati Tuhan bahkan bersatu dengan Tuhan melalui Nitr Muhammad. Namun demikian hanya manusia yang berpredikat insan $k d m i l$ sajalah yang bisa mendekati Tuhan bahkan bersatu dengan-Nya. Dari segi syaria't, wujud insan kamil adalah Nabi Muhammad, sedangkan hakekat adalah Nur Muhammad, atau haqtqal Muhammad. Hubungan keduanya dapat digambarkan seperti ini: Nabi Muhammad merupakan koridor menuju kepada insan kamil, yaitu hakekat "bayangan" Tuhan. Orang Islam berminat menuju sampai bertemu dengannya harus melewati koridor ini yaitu mengikuti jejak langkah Nabi Muhammad. ${ }^{26}$

Nitr Muhammad biasa juga disebut dengan Haqiqat Muhammad. Syaikh Samman mengatakan bahwa Nitr Muhammad, itu adalah salah satu rahasia dari seluruh rahasia Allah yang kemudian diberinya maqdm. Nur Muhammad adalah pertama kali mewujud sebelum lainnya berwujud, sedangkan wujudnya adalah hakekat atau esensi wujud alam mi.Nur Muhammad adalah pangkal terbentuknya alam semesta dan memang dari wujudnya generasi segala makhluk terjadi. ${ }^{27}$
Setelah menganalisa isi naskah Hakekaq Sampajang, maka dapat dipahami bahwa pemikiran-pemikiran dalam naskah tersebut seperti yang ditulis oleh penulis tidaklah bertentangan dengan konsep-konsep ajaran Islam baik syariat, tarekat, maupun hakekat untuk sampai pada Tuhan. Dalam Naskah ini penulis menjelaskan pemahaman untuk sampai pada Tuhannya berbagai cara yang harus ditempuh seperti tarekat untuk sampai pada hakekat dalam rangka mengungkap tabir Allah (ma 'rifatullah).

Pemikiran-pemikiran yang diungkap dalam naskah tersebut, jika dikaji secara mendalam tidak jauh berbeda dengan apa yang dituliskan pada beberapa naskahnaskah lainnya baik naskah bugis maupun naskah melayu terutama pada penyatuan hamba dan Tuhan dengan konsep wahdat al-wujud, demikian pula konsep dzikir yakni dzikir empat, yang terdapat pada tarekat khalwatiyah, sattariyah, maupun naqsabandiyah. Tidak ada perbedaan yang satu dengan yang lainnya.

\section{PENUTUP}

\section{Kesimpulan}

Dari penjelasan pokok bahasan yang menjadi kajian penelitian tentang naskah hakekat sempajang (HS) maka dapatlah diambil beberapa kesimpulan sebagai berikut:

1. Naskah hakekaq sampajang terdiri dari empat pasal dua pasal menjelaskan tentang hakekat shalat dan dua pasal lainnya menjelaskan tentang zakratul maut dan tanda-tandanya, konteksnya lebih mengarah pada pemahaman tasawuf dan tarekat dalam memahami shalat, dzikir, tandatanda kematian.

2. Konsep shalat yang terdapat dalam naskah HS bahwa shalat tidak saja dilakukan secara dzahiriah tetapi juga secara batiniah untuk sampai pada hakekat shalat yang sebenarnya, maka yang harus dipahami adalah bukan pada gerakan tubuh kasar semata melainkan pada gerakan batin sehingga dalam shalat pikiran dan hati hanya tertuju pada Allah semata.

\footnotetext{
${ }^{25}$ Kesiapan yang dimaksudkan adalah kondisi al-Khalq (seseorang atau alam atau mahkluk) dalam menerima penyatuaannya dengan sang pencipta (al-haqq) yang diperoleh melalui suatu metode pendekatan dengan Allah SWT.,sebagaimana telah banyak didiskusikan tentang tingkatan yang dilalui oleh para penganut ajaran kerohanian yang substansi ajarannya adalah kesatuan wujud.

${ }^{26}$ Ahmad Abrori. 2004. Tarekat Sammaniyah Sejarah Perkembangan Ajarannya, dalam Mengenal dan Memahami Tarekat-tarekat Muhktabara di Indonesia, Jakartag: Prenada Media, h. 210.

Ibid., h. 208.
} 
3. Konsep dzikir yang termuat dalam naskah HS terdapat empat tingkatan dan hendaklah diamalkan ketika ajal akan segera dating sehingga setiap hamba mendapatkan Nur Muhammad untuk mengetahui hakekat dirinya dan hakekat Allah Swt.

4. Terdapat empat tanda-tanda kematian yang dijelaskan dalam naskah HS, jika keempat tanda kematian tersebut diketahui oleh seorang hamba di akhir ajalnya, niscaya akan mendapatkan keselamatan dari Allah Swt.

\section{Rekomendasi:}

1. Pengkajian teks naskah masih perlu dilakukan dalam rangka mengungkap nilai-nilai keagamaan yang terkandung di dalamnya terlebih pada naskah yang keagamaan khususnya tasawuf memiliki nilai keilmuan yang cukup tinggi terkait corak pemikiran yang dituangkan oleh para ulama-ulama dahulu.

2. Pengkajian terhadap teks naskah diharapkan dapat dilakukan secara berkesinambungan dalam rangka mengungkap corak keagamaan, khazanah budaya pada masa lalu dan relevansinya dengan kondisi masyarakat kekinian.

\section{Ucapan Terima Kasih}

Penelitian ini merupakan penelitian kompetitif dilakukan pada tahun 2009 yang dibiayai oleh DIPA Balai Penelitian dan Pengembangan Agama Makassar. Ucapan terima kasih diperuntukkan kepada Kepala Balai Litbang Agama Makassar dan berbagai pihak yang telah berpartisifasi atas terlaksananya penelitian ini.

\section{DAFTAR PUSTAKA}

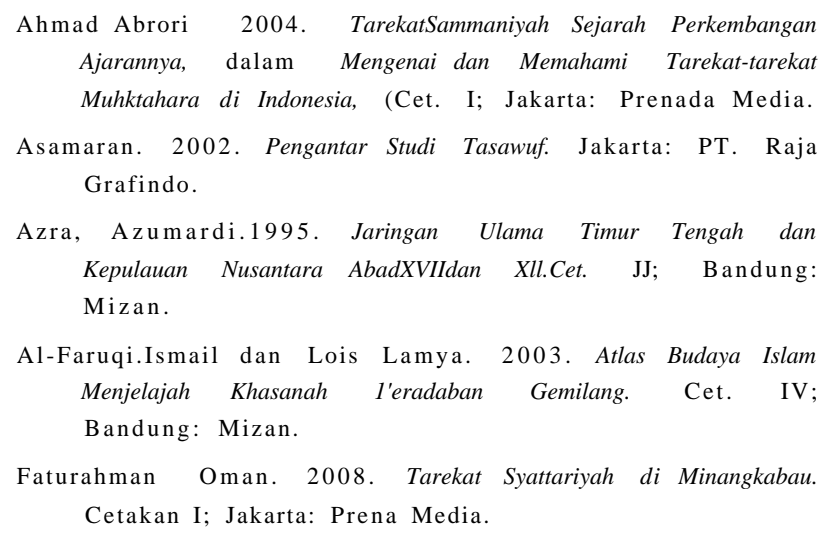

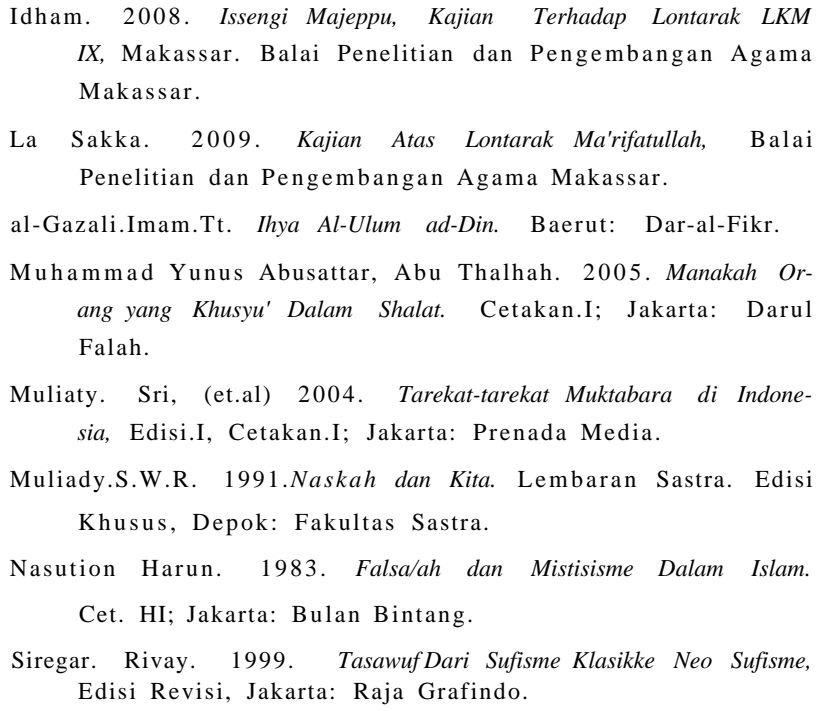

